\title{
Nedocromil sodium: a new drug for the management of bronchial asthma
}

\author{
S LAL, S MALHOTRA, D GRIBBEN, D HODDER \\ From the General Hospital, Bury, and Fisons Pharmaceuticals, Loughborough
}

ABSTRACT Nedocromil sodium (FPL 59002) is a pyranoquinoline dicarboxylic acid that has been developed for the management of bronchial asthma. We report the results of a double blind group comparative trial in which the disodium salt of nedocromil delivered by pressurised aerosol and a placebo were compared in the management of patients with a diagnosis of bronchial asthma who entered the double blind period on a minimum dose of beclomethasone dipropionate. In almost all the assessments of clinical activity nedocromil sodium was shown to be more effective than placebo. These include improvements in diary card symptom scores, reduction in concomitant use of a bronchodilator aerosol, and patients' and investigators' assessments of efficacy. Unwanted effects were few and mild. No patients were withdrawn from the trial.

Nedocromil (FPL 59002) is a pyranoquinoline dicarboxylic acid (chemical name 9-ethyl-6, 9-dihydro-4,6-dioxo-10-propyl-4H-pyrano (3,2-g) quinoline-2,8-dicarboxylic acid) and its disodium salt (FPL 59002KP) was identified from a range of pharmacological and immunological tests as a compound worthy of clinical evaluation in asthmatic patients. In antigen challenge studies nedocromil sodium was shown to protect against the immediate reaction, and the results suggested that the compound may be useful in the treatment of bronchial asthma.

We report here the results of a double blind group comparative trial of nedocromil sodium and placebo in the management of patients with bronchial asthma who were currently being treated with beclomethasone dipropionate and a $\beta_{2}$ adrenergic agonist bronchodilator aerosol to control their symptoms.

\section{Patients and methods}

The purpose of the trial was explained to the patients and their consent obtained. Forty patients who were taking beclomethasone dipropionate and inhaled $\beta_{2}$ adrenergic agonists as their sole treatment for asthma were selected as they presented at outpatient clinics during two months. Their dose of

Address for reprint requests: Dr S Lal, General Hospital, Bury, Lancs BL9 6PG.

Accepted 4 June 1984 beclomethasone dipropionate was then so adjusted over a few weeks that they were having the minimum dose of beclomethasone required to keep them in a stable state. During this phase they also kept a diary card to record their symptoms, the frequency of use of a bronchodilator aerosol, and the dose of beclomethasone dipropionate currently being used.

Nine patients were found to have minimal symptoms even when beclomethasone dipropionate was discontinued altogether. These patients were then managed with a $\beta_{2}$ agonist only and did not take further part in the study. One group received nedocromil sodium at a dose of $4 \mathrm{mg}$ (two inhalations of $2 \mathrm{mg}$ from a pressurised aerosol) four times daily. The other group received two inhalations four times daily from an identical placebo pressurised aerosol containing the same propellants and surfactant but without the active drug. Both treatments were continued for 28 days. Before starting on the trial aerosols each patient completed a diary card for two weeks to establish baseline values. They rated symptoms of night time and daytime asthma, morning chest tightness, and cough on a $0-4$ scale related to each symptom-for example, night asthma would be rated from 0 (undisturbed sleep) to 4 (being awake all night). Patients were supplied with a mini Wright peak flow meter and they recorded the best of three readings morning and evening on the diary card. They also recorded all medication taken, including the test medication.

At each clinic visit the severity of the patient's 
asthma was assessed on a $0-4$ scale (0-no symptoms, 1-mild, 2-moderate, 3-severe, 4-very severe). FEV 1 and FVC were measured with a Vitalograph and peak expiratory flow rate (PEFR) was checked using the patient's own peak flow meter. Patients were asked about complaints which might be considered adverse reactions to the trial treatment and these were rated on the assessment forms as possibly, probably, or unlikely to be due to treatment or "don't know." Before and after the trial treatment blood and urine samples were taken for routine analysis.

Only patients with a score of 2 or more for at least one asthma symptom for seven days or a PEFR variability of $20 \%$ were included in the double blind period of the trial. They were also required to show that they were able to use a pressurised aerosol and peak flow meter correctly and that they understood how to complete the diary card. The results of routine haematological investigations; urea, electrolyte, liver function tests, and urine analysis were required to be within the normal limits.

Test treatments were assessed on the basis of the data recorded at clinic visits, the diary cards, and laboratory analysis of blood and urine samples. Statistical significance was based on a $p$ value of 0.05 or less (two tailed Mann-Whitney test).

\section{Results}

Thirty one patients entered the double blind part of the study, 14 taking nedocromil and 17 placebo. There were 11 men and three women having nedocromil and their ages ranged from 32 to 69 (mean $48)$ years. There were eight men and nine women in the placebo group, aged 19-62 (mean 43) years. The groups were not matched for sex but this was not considered necessary. The type, duration, and severity of asthma were similar in each group. One patient having nedocromil was excluded from the analysis because of non-compliance with the test treatment.

Mean symptom severity scores of daytime and night time asthma, morning tightness and cough, and use of a bronchodilator aerosol were calculated from the diary cards for each week of the double blind period and were compared with means in the baseline period. Results are shown in tables 1 and 2 .

Mean decreases in severity scores were greater in the nedocromil group than in the placebo group for all symptoms and differences between the groups were significant for daytime asthma for all treatment weeks. Differences in morning tightness were significant for the first and second weeks and for cough in weeks 1 and 4.

Table 1 Analysis of diary card symptom scores*

\begin{tabular}{|c|c|c|c|c|}
\hline & \multicolumn{2}{|l|}{ Mean score } & \multirow{2}{*}{$\begin{array}{l}\text { Mann-Whitney U statistic } \\
\text { for placebo }\end{array}$} & \multirow[t]{2}{*}{ Significance (p) } \\
\hline & Nedocromil $(n=13)$ & Placebo $(n=17)$ & & \\
\hline $\begin{array}{l}\text { DAYTIME ASTHMA } \\
\text { Baseline } \\
\text { Difference from baseline } \\
\text { in week: }\end{array}$ & $1 \cdot 26$ & $1 \cdot 30$ & & \\
\hline $\begin{array}{l}1 \\
2 \\
3 \\
4\end{array}$ & $\begin{array}{l}-0.57 \\
-0.64 \\
-0.66 \\
-0.65\end{array}$ & $\begin{array}{l}-0 \cdot 04 \\
-0 \cdot 29 \\
-0 \cdot 16 \\
-0 \cdot 17\end{array}$ & $\begin{array}{l}42 \\
61 \\
58 \\
63\end{array}$ & $\begin{array}{l}<0.01 \\
<0.05 \\
<0.05 \\
<0.05\end{array}$ \\
\hline $\begin{array}{l}\text { NIGHT TIME ASTHMA } \\
\text { Baseline } \\
\text { Difference from baseline }\end{array}$ & 0.58 & 0.64 & & \\
\hline $\begin{array}{c}\text { In week: } \\
1 \\
2 \\
3 \\
4\end{array}$ & $\begin{array}{l}-0.39 \\
-0.42 \\
-0.40 \\
-0.38\end{array}$ & $\begin{array}{l}-0.26 \\
-0.26 \\
-0.24 \\
-0.22\end{array}$ & $\begin{array}{l}87 \cdot 5 \\
80 \\
87 \\
90\end{array}$ & $\begin{array}{l}\text { NS } \\
\text { NS } \\
\text { NS } \\
\text { NS }\end{array}$ \\
\hline $\begin{array}{l}\text { MORNING TIGHTNESS } \\
\text { Baseline } \\
\text { Difference from baseline }\end{array}$ & 1.48 & $1 \cdot 42$ & & \\
\hline $\begin{array}{c}\text { in week: } \\
1 \\
2 \\
3 \\
4 \\
\end{array}$ & $\begin{array}{l}-0.75 \\
-0.75 \\
-0.83 \\
-0.73\end{array}$ & $\begin{array}{l}-0.02 \\
-0.11 \\
-0.32 \\
-0.28\end{array}$ & $\begin{array}{l}50 \\
63 \cdot 5 \\
64 \cdot 5 \\
73\end{array}$ & $\begin{array}{l}<0.05 \\
<0.05 \\
\text { NS } \\
\text { NS }\end{array}$ \\
\hline $\begin{array}{l}\text { cougH } \\
\text { Baseline } \\
\text { Difference from baseline } \\
\text { in week: }\end{array}$ & 0.76 & 0.86 & & \\
\hline $\begin{array}{l}1 \\
2 \\
3 \\
4\end{array}$ & $\begin{array}{l}-0.30 \\
-0.32 \\
-0 \cdot 47 \\
-0.50\end{array}$ & $\begin{array}{l}+0 \cdot 12 \\
+0 \cdot 07 \\
-0 \cdot 13 \\
-0 \cdot 10\end{array}$ & $\begin{array}{l}59 \\
72 \\
73 \\
59\end{array}$ & $\begin{array}{l}<0.05 \\
\text { NS } \\
\text { NS } \\
<0.05\end{array}$ \\
\hline
\end{tabular}

*0-4 scale: 0 indicates no symptoms and 4 very severe (means for two week baseline and each week of double blind period). 
Table 2 Mean (SD) peak expiratory flow rates (PEFR)*

\begin{tabular}{|c|c|c|c|c|}
\hline & \multicolumn{2}{|l|}{ litres/min } & \multirow[t]{2}{*}{$t$ statistic } & \multirow[t]{2}{*}{ Significance $(p)$} \\
\hline & Nedocromil $(n=12)$ & Placebo $(n=15)$ & & \\
\hline $\begin{array}{l}\text { MORNING PEFR } \\
\text { Baseline } \\
\text { Difference from baseline } \\
\text { in week: }\end{array}$ & $345(87)$ & $344(100)$ & & \\
\hline $\begin{array}{l}1 \\
2 \\
3 \\
4\end{array}$ & $\begin{array}{l}17(44) \\
27(47) \\
26(55) \\
23(55)\end{array}$ & $\begin{array}{r}4(23) \\
18(32) \\
12(29) \\
8(25)\end{array}$ & $\begin{array}{l}0.97 \\
0.57 \\
0.83 \\
0.93\end{array}$ & $\begin{array}{l}\text { NS } \\
\text { NS } \\
\text { NS } \\
\text { NS }\end{array}$ \\
\hline $\begin{array}{l}\text { EVENING PEFR } \\
\text { Baseline } \\
\text { Difference from baseline }\end{array}$ & $(n=10)$ & $346(97)$ & & \\
\hline $\begin{array}{l}1 \\
2 \\
3 \\
4\end{array}$ & $\begin{array}{l}15(44) \\
19(52) \\
23(56) \\
19(47)\end{array}$ & $\begin{array}{l}9(32) \\
23(36) \\
15(35) \\
20(28)\end{array}$ & $\begin{array}{r}0.41 \\
-0.22 \\
0.41 \\
-0.06\end{array}$ & $\begin{array}{l}\text { NS } \\
\text { NS } \\
\text { NS } \\
\text { NS }\end{array}$ \\
\hline
\end{tabular}

*Best of three measurements on each occasion.

Mean PEFR values for the treatment period were compared with mean values for the baseline. Readings taken within four hours of an inhalation of a bronchodilator were excluded. Only those patients for whom complete data were available (12 having active and 15 placebo preparations for the morning peak flow rate, 10 having active and 15 placebo preparations for the evening) were included in the analysis.

Mean PEFR increased in both groups and no significant differences were noted between groups (table 2). Use of inhaled bronchodilators fell in both groups during the study and this fall was significantly greater in the nedocromil treated group during three weeks of the treatment period (table 3).

Patients' as well as the investigator's ratings of the effectiveness of treatment were significantly in favour of nedocromil. Of the 13 patients taking nedocromil, 11 thought the treatment was very effective or moderately effective, one considered it slightly effective, and one not effective at all. No patient thought his or her condition had been made worse. On the other hand, of the 17 patients taking placebo, eight thought that the treatment was very effective or moderately effective and one patient thought that it was slightly effective, but another seven found no effect and one felt that his condition was made worse. Differences between groups were significant at the 5\% level with the Mann-Whitney test. The investigator also rated nedocromil as more effective than placebo $(p<0.01)$.

Complaints that might have been adverse reactions to treatment were few and relatively mild in both groups. Four patients taking nedocromil sodium had complaints. One patient complained of cough and loss of voice and one of headache and a sore throat; one said that the aerosol had a bitter taste. One patient complained of dizziness but this was not thought by the investigator to be drug related. Three patients having placebo had com-

Table 3 Daily use of bronchodilator aerosol

\begin{tabular}{|c|c|c|c|c|}
\hline & \multicolumn{2}{|c|}{ Mean number of inhalations } & \multirow{2}{*}{$\begin{array}{l}\text { Mann-Whitney U statistic } \\
\text { for placebo }\end{array}$} & \multirow[t]{2}{*}{ Significance ( $p$ ) } \\
\hline & Nedocromil $(n=13)$ & Placebo $(n=17)$ & & \\
\hline $\begin{array}{l}\text { DAYTIME USE } \\
\text { Baseline } \\
\text { Difference from baseline }\end{array}$ & $3 \cdot 68$ & $3 \cdot 74$ & & \\
\hline $\begin{array}{l}\text { in week: } \\
1 \\
2 \\
3 \\
4\end{array}$ & $\begin{array}{l}-2 \cdot 30 \\
-2 \cdot 28 \\
-2 \cdot 33 \\
-2 \cdot 43\end{array}$ & $\begin{array}{l}-0.83 \\
-1.18 \\
-1.17 \\
-1.30\end{array}$ & $\begin{array}{l}54 \\
65 \\
57 \cdot 5 \\
58 \cdot 5\end{array}$ & $\begin{array}{l}<0.05 \\
\text { NS } \\
<0.05 \\
<0.05\end{array}$ \\
\hline $\begin{array}{l}\text { NIGHT TIME USE } \\
\text { Baseline } \\
\text { Difference from baseline } \\
\text { in week: }\end{array}$ & 0.97 & $1 \cdot 05$ & & \\
\hline $\begin{array}{l}1 \\
2 \\
3 \\
4\end{array}$ & $\begin{array}{l}-0.47 \\
-0.48 \\
-0.60 \\
-0.53\end{array}$ & $\begin{array}{l}-0.24 \\
-0.29 \\
-0.24 \\
-0.12\end{array}$ & $\begin{array}{l}87 \\
87 \cdot 5 \\
61 \cdot 5 \\
70\end{array}$ & $\begin{array}{l}\text { NS } \\
\text { NS } \\
<0.05 \\
\text { NS }\end{array}$ \\
\hline
\end{tabular}


plaints, two of cough and one of a rash. No patient was withdrawn from the trial because of a suspected adverse reaction.

There were no treatment related changes in haematological findings, blood biochemistry or urine analysis done before and after treatment.

\section{Discussion}

Others working on the pharmacotherapy of asthma have drawn attention to the difficulty of predicting the clinical activity of new agents on the basis of preclinical screening tests. ${ }^{123}$ In the clinic the assessment of a new drug in the management of asthma presents difficulties. ${ }^{4}$ Newly diagnosed patients would prefer to have their symptoms controlled as soon as possible, and once symptoms are controlled with the available drugs it becomes difficult to assess the part the new compound would play in the management of these patients. On the other hand, patients with so called stable asthma may be at their best on entry to the trial and therefore room for improvement in either symptoms or results of pulmonary function tests is limited.

Secondly, even those with stable asthma have variability in their symptoms, due not only to the nature of the disease but also changes in external influences like the weather. If possible, the trial should be arranged in such a manner that external influences affect all patients equally. In the present study all 31 patients were entered into the trial concurrently to avoid variability of external influences.

It is, of course, preferable to admit into the trial asthmatics who have assessable indices such as frequency of use of bronchodilator treatment, variations in which could indicate improvement or deterioration. In this study we attempted to control as many of the variables as possible. Nine patients were excluded after the first phase because of insufficient symptoms. The remaining 31 patients studied can be regarded as truly needing and benefiting from preventive treatment with beclomethasone dipropionate. Although regular measurement of peak expiratory flow rate offers a sensitive objective measure of progress, the information provided by this means may be of limited value if peak expiratory flow rate is near normal at the time of entry into the trial, or if bronchodilator use is varied. Peak expiratory flow rate in almost all subjects was close to the expected normal for their age and height and, as expected, the peak expiratory flow rate recorded by our patients at home was not significantly different in the two groups. The use of $\beta_{2}$ adrenergic agonists decreased in both groups but the fall was greater in the group taking the active drug. Subjective assessment by patients and observers showed a significant preference for nedocromil sodium over placebo.

In conclusion, we have shown that nedocromil sodium has a clinically significant therapeutic effect and is worthy of further consideration in the management of bronchial asthma.

\section{References}

${ }^{1}$ Church MK. Cromoglycate-like anti-allergic drugs. A review. Medicamentos de Actualidad (Drugs of Today) 1978; 14:281-341.

${ }^{2}$ Auty RM. New Drugs for Allergy \& Asthma Under Investigation in the USA and Abroad. Immunology and Allergy Practice 1983;5:44-53.

${ }^{3}$ Davies RJ, Moodley I. Anti-allergic compounds. Pharmacol Ther 1982;17:279-97.

${ }^{4}$ Rees J. Clinical Trials in Asthma. Br Med J 1983;287:376-7. 